\title{
DUTCH COLONIAL LITERATURE: ROMANTICISM IN THE TROPICS
}

\author{
E. M. Beekman
}

On the twenty-third of June 1596, four Dutch ships appeared off the coast of Bantam on the island of Java. Their arrival marked the beginning of Dutch presence in what were then known as the East Indies. Expanding their interests from a purely mercantile venture to an agricultural enterprise, and, finally, to a colonial empire, the Dutch remained there for nearly three and a half centuries.

At the time of this first voyage the Dutch were already renowned as maritime traders, being, as Defoe characterized them, "the Factors and Brokers of Europe . . their vast Commerce consists in being supply'd from All Parts of the World, that they may supply All the World again."I

Perhaps no other European nation had gathered so much practical information as Holland did before it sent its own Argonauts to the fabled Spice Islands. ${ }^{2}$ It could rely on improved cartography, on what were called "mapbooks" or "reading maps" (atlases), and on a variety of "mirrors" or "treasuries" of the art of navigation. All this material had been charted or compiled by some of the foremost experts of that time such as Mercator, Ortelius, Plancius, Waghenaer, and Willem Barents.

The most influential figure was Jan Huygen van Linschoten $\left(1563\right.$ ?-1611). ${ }^{3}$ He left Holland at the age of sixteen and did not return until more than thirteen years later. During that time he was in Portuguese service for nine years, living mostly in Goa, the capital of Portuguese India. When he returned to the town of Enkhuizen in northern Holland he wrote his Itinerario or the Voyage of Jan Huygen van Linschoten to the East or Portugal's Indies. Published in 1596, it was a work based on his own experiences as well as a compilation of other sources. Van Linschoten later added what was called a "rutter" or "pilot's guide" in English. " This was a practical handbook for mariners. It is very likely that a copy of van Linschoten's "rutter," with its crucial information on courses and sailing directions, was taken along on that first scouting expedition. But what is also important for our present

1. Quoted in Charles Wilson, The Dutch Republic and the Civilisation of the Seventeenth Century (New York: McGraw-Hill, 1968), p. 22.

2. A description of the first Dutch voyages to the Indies can be found, among many others, in F. W. Stapel, Geschiedenis van Nederlandsch Indië, 5 vols. (Amsterdam: Joost van den Vondel, 1938-1940), 2, pp. 277-98; 321-52.

3. On van Linschoten, see Stapel, Geschiedenis, 2, pp. 289-98. There is a biography of him in English: Charles Mckew Parr, Jan van Linschoten: The Dutch Marco Polo (New York: Crowell, 1964).

4. For rutters and early travel literature see also Rob Nieuwenhuys, Oost-Indische Spiegel. Wat Nederlandse schrijvers en dichters over Indonesië hebben geschreven, vanaf de eerste jaren der Compagnie tot op heden (Amsterdam: Querido, 1972), pp. 19-43. 
purpose is that van Linschoten's efforts were not only motivated by patriotic practicality but by something more serendipitous as well. He wanted to know "what the world had in it" after he read stories which "greatly incited [his] desire to see strange and unknown countries and to pursue diverse adventures."

Van Linschoten's motto was "souffrir pour parvenir" which can be succinctly translated as "pain for gain." Such was certainly the case for the Argonautic exploits of the seventeenth century, if not for colonialism as a whole. During their first voyage, for instance, a great deal was suffered for very little gain. The expedition, which lasted from 1595 to 1597, was not commanded by a single authority but by a kind of committee of both merchants and mariners. But it soon became apparent that a senior merchant by the name of Cornelis de Houtman had assumed the most power. This was unfortunate, because de Houtman was an ambitious and unscrupulous man, a bully who lacked any qualities of leadership. With him traveled his younger brother Frederick, a man of character and civility.

The journey was a dismal affair. There was constant bickering and intrigue among the nominal leaders who connived and informed against one another to serve their own purposes. Though the ships had been newly built, they proved to be far from seaworthy. When they were still six months away from Bantam Bay, half of the crew had already been lost to disease and hostilities, and it took them altogether fourteen months to reach the Indies.

Though they had come all that way to negotiate trade agreements, the conduct of the Dutch was a travesty of diplomacy. They proved to be obstinate, tactless, peremptory, and violent. Their Portuguese rivals had no trouble persuading the regent of Bantam that he should deny the Dutch access to pepper and other goods, and the negotiations with Bantam royalty ended in a battle. Nor did they fare any better further east in Java, in a settlement called Djakatra, or in the neighboring island of Sumatra. They fought a bloody battle against pirates from Sidaju, and the day after, they killed a large number of innocent Madurans because the crew feared another attack. The leaders fought about what to do next, de Houtman was suspected of poisoning a captain, one ship simply left for home, while another was burned because there were not enough sailors to man it. The only high point of the journey was their sojourn in Bali, an island so attractive after the horrors they had experienced that two crew members volunteered to get fresh drinking water and never returned. After having been away for almost two-and-a-half years, the ships came back to Holland with only eighty-nine men left of the original 249; eight more died at home. They brought very little merchandise back with them, but, despite everything, they could claim to be the first Dutchmen to have reached the Indies.

Between 1598 and 1601 altogether sixty-five ships sailed from the Netherlands to Java and the Moluccas (or Spice Islands), with much better results because they were commanded by capable individuals. But another voyage commanded by Cornelis de Houtman, with his brother as captain of one of the ships, was also a disaster. Their destination was Atjeh, a sultanate on the northern tip of Sumatra, to buy pepper. This time de Houtman fell victim to the byzantine intrigues of Holland's Portuguese rivals at the court of the sultan. A large force of Atjehers attacked the two ships. They killed Cornelis and nearly one hundred members of his crew, and took about thirty men prisoner. Among them was Frederick de Houtman. During his nearly two years of captivity, Frederick showed himself to be superior to his luckless brother, and a worthy successor to van Linschoten. Often in danger of his life, he taught himself the Malay language and studied the constellations of the southern hemisphere. Upon his return to Holland he published in 1603 a dictionary and phrasebook of Malay, as well as a description of "the Declination of many Stars, standing around the South-pole, never seen before this time." 
Both his astronomical observations of the tropical heavens and his book on spoken Malay were the first of their kind ever to be published in Europe. ${ }^{5}$ But like van Linschoten, Frederick de Houtman recommended his book not only for practical reasons to "those who visit the Lands of the East-Indies" but also in the hope that it would be "no less delightfull to all those who are curious Lovers of strangeness."

From the example of van Linschoten and Frederick de Houtman one can conclude that, at the outset of Dutch colonialism, there were two crucial requirements for the foundation of any civilization--utilitarian pragmatism and intellectual curiosity. The romantic desire for adventure could still have practical consequences, while commercial enterprise still had an air of bold inventiveness about it. We know that this did not last, but for some time reality seemed remarkably close to romance, and romance was far sturdier than fantasy. It is this aesthetic dimension of colonialism I want to discuss here in literary terms, not ideology or politics. Generally speaking one will find the nature of colonial literature paradoxical because the intellectual and imaginative forces which had been part of the fabric of everyday life were eventually declared unprofitable and incompatible by the conformist actuality of an institutionalized imperialism. But that irrepressible force could not be denied, and it surfaced once again in the nineteenth century in the more familiar form of literature and intellectual nonconformity.

The point I wish to make is that from the very beginning the driving force of Dutch colonialism was not only mercantile but also imaginative. At first realism and romance were still compatible, though the latter would always be sacrificed to expediency if circumstances demanded it. For some time sense and sensibility were not yet entirely divorced from each other; they could, indeed, sustain one another.

If we read the best of the colonial literature, it was most definitely unorthodox by traditional standards. Although the poetry and drama were lamentably bad and inferior, exquisite lyrical descriptions appear, for instance, in the work of the seventeenth-century botanist Rumphius, or dramatic evocations of tropical landscapes emerge in Junghuhn's nineteenth-century scientific treatise on Java's volcanoes. ${ }^{6}$ In conventional terms, the most uncouth texts of all were the travel books and journals of the seventeenth and early eighteenth centuries. The majority of them were, in Gerrit de Veer's expressive phrase, "sailage" narratives, like that of van Linschoten, or de Veer's own account of the dramatic wintering on the island of Nova Zembla, ${ }^{7}$ or the sober recitation of the events that became known as the Adventurous Journey to the East-Indies of Willem Ysbrantsz Bontekoe. ${ }^{8}$ Bontekoe's stoical description of his extraordinary bad luck was so popular that his name became part of the Dutch language in the expression "een reis van Bontekoe" ("a journey like Bontekoe's"), that is to say, a trip that is uncommonly difficult and accident prone.

5. For Frederick de Houtman and his work, see the modern edition of his Malay phrase-book, Le "Spraeck ende Woord-Boek" de Frederick de Houtman. Première méthode de malais parlé (fin du XVIe s.), ed. Denys Lombard (Paris: École Française d'extrême-orient, 1970); see especially the introduction, pp. 1-12.

6. See: E. M. Beekman, The Poison Tree. Selected Writings of Rumphius on the Natural History of the Indies (Amherst: University of Massachusetts Press, 1981), and Frans Junghuhn, Java, zijne gedaante, zijn plantentooi en inwendige bouw, 4 vols., 2d ed. (The Hague: Mieling, 1853).

7. See Gerrit de Veer, Overwintering op Nova Zembla (Utrecht: Spectrum, 1978).

8. Willem Ysbrantsz. Bontekoe, Memorable Description of the East Indian Voyage 1618-25, ed. P. Geyl, trans. Mrs. C. B. Bodde-Hodgkinson (London: Routledge, 1929). 
These accounts of travel were extremely popular in the seventeenth century, because they satisfied the romantic imagination of the more sedentary citizens at home who could travel in this fashion without leaving their armchairs. They were tales of adventure which entertained, though that does not mean that their utilitarian nature went unnoticed. The dual purpose remarked on earlier, wanting to instruct as well as delight, remained a characteristic feature. And even if these Dutch accounts were not collected in a politically motivated anthology, such as Hakluyt did for British voyages and discoveries, they can still-be said to represent, in Irwin Blacker's words, "the very papers of empire." 9 For the Dutch travelogues did also provide geographical and navigational information, they investigated the mercantile potential of foreign regions, and, perhaps most importantly, spoke to the next generation of seafarers with the voice of experience.

This early literature is also the stylistic precedent for a later mode of writing that I would associate with the best of Dutch colonial literature. Such men as van Linschoten or Bontekoe had no literary pretensions. They presented their experiences simply and straightforwardly. In fact, van Linschoten had to be persuaded to publish his Itinerario, 10 and the same was true for the modest Bontekoe who felt-according to his publisher the printer Jan Deutel of Hoorn--that he had not described his experiences in "a style [that] was, in his opinion, suitable to be printed."II It was an honest style, one that attests to the original meaning of the word "aesthetic," that is to say "to be able to perceive." That we can now also dub it aesthetic in a more intellectual sense is only to the honor of those early writers. Van Linschoten begged his readers' pardon for his "small skill, labor and uninstructed manner of writing" and warned them not to look in his book for "singular gallantries" because they would only find "natural and true descriptions." Bontekoe's publisher made similar claims on his author's behalf: "here you will find no trifling, nor dreams, nor fabulous imaginings. Nor was this description made on hearsay . . . [but] it is based on personal experience, relating what miracles God performed by the author himself and those who were with him."

These early authors allowed their extraordinary experiences to energize their narratives without having to resort to rhetoric. In effect this meant that realism was romance, that what was ordinary under these circumstances would elsewhere be received as remarkable, that fact could be like fiction, that sense could be discerning as well as sensual. And those subsequent colonial writers who took the literary lesson of these humble tales to heart profited from it. A writer was far freer in the Indies to develop what we now consider a modern style, because he would not be intimidated by literary conventions and did not need to answer to Europe. The result was that four of Dutch literature's modern prose masterpieces were written in or about the Indies by authors who were either born in the Indies or spent their formative years there: Multatuli's Max Havelaar, Couperus' De stille kracht (The Hidden Force), Du Perron's Het land van herkomst (Country of Origin), and Maria Dermoût's De Tienduizend dingen (The Ten Thousand Things).

9. See: Hakluyt's Voyages, ed. Irwin R. Blacker, in the Viking "Portable Series" (New York: Viking Press, 1965), p. 1.

10. Jan Huyghen van Linschoten, Itinerario. Voyage ofte Schipvaert van Jan Huyghen van Linschoten naer Oost ofte Portugaels Indien, ed. H. Kern, 5 vols. (The Hague: Nijhoff, 1910-1939).

11. Bontekoe, Memorable Description, pp. 2-3. 
In his perceptive study entitled Dreams of Adventure, Deeds of Empire. ${ }^{12}$ Martin Green studied the relationship between adventure tales and British imperialism, pointing out, correctly it seems to me, that imperialism and colonialism were sustained by a contradiction. Although the reasons for establishing a tropical colony were entirely mercantile, the original driving force came from what Green calls the "aristomilitary caste." These two forces are seldom at ease with one another and they will create a field of tension that may be constructive at first, but that will inevitably become antagonistic. And though the aristocratic element is far less pronounced in Dutch history and society, some parallels with England cannot be denied. Especially in the first century and a half of Dutch colonialism, the Indies provided a chance for young men--the emphasis on youth is important--of modest social background to aspire to, and actually realize, a life that, back in Europe, could only be enjoyed by the upper classes. Time and again one will hear of ambitious young Dutchmen rising to the most prestigious positions in the colonial hierarchy. One can mention such figures as Coen, Maetsuycker, Van Rhede tot Drakesteyn, Camphuys, and Speelman. Such a fabled existence became the major ingredient of a myth which, ironically, only served to strengthen middle-class capitalism.

What Green mentions about British India was also true of the Dutch colony: there one could find the "living promise of lordship or royalty." 13 Perhaps the most telling symbol of this romance of power was the golden payung or parasol which was described by Couperus in De stille kracht as a "furled sun." The custom of having the payung always present when a high Dutch official made a public appearance--even when he simply went for a walk or a drive--was copied from Javanese aristocracy and was not officially abolished until 1904. This aspect of colonialism always represented, for good or ill, the romance of colonialism. But this was deceptive because, no matter how alluring it might be, the objective was not romantic indulgence but hard cash. And the latter has seldom failed to compromise the former.

One could, in fact, describe the development of colonialism from the seventeenth to the twentieth century as a gradual transition from an age of heroism to one of prudence. ${ }^{14}$ In her study of The Origins of Totalitarianism, Hannah Arendt made a similar distinction between the earlier era of colonial trade and imperialism. The earlier period of time employed adventurers who had "stepped out of society" and were, in European terms, "enterprising beyond the permitted limits of civilization." These were true individuals of "their own making" who lived, in Conrad's words, in "a world of hazard and adventure." Arendt sums up such figures by referring to Lawrence of Arabia who, she says, represents "the end of the real pride of Western man who no longer counts as an end in himself, no longer does 'a thing of himself nor a thing so clean as to be his own' by giving laws to the world, but has a chance only 'if he pushes the right way' in alliance with the secret forces of history and necessity--of which he is but a function."15

This singleton represents the older world of colonial trade that was replaced by institutionalized imperialism in the form of the huge bureaucracy of the colonial civil

12. Martin Green, Dreams of Adventure, Deeds of Empire (New York: Basic Books, 1979), pp. 16-20.

13. Ibid., p. 114 .

14. Ibid. (quoting Coleridge), p. 102.

15. The quotations in this paragraph are from Hannah Arendt, The Origins of Totalitarianism [Second Enlarged Edition] (Cleveland: World Publishing Co., 1958), pp. $187,189,190,220-21$. 
service. The historical corollary is the demise of the United East India Company at the end of the eighteenth century. In psychological terms one can say that, when the Company ceased to exist and the commercial enterprise became a colonial empire, hazard was replaced by administrative necessity, adventure was negated by legislation, and boundaries of the mind as well as the map were no longer limitless but carefully circumscribed by government directives. The colonial empire was not interested in individuals but found its strength in numbers, its reward in diligence. To be sure, the myth of tropical potentiality, excess, luxury, and romance persisted and attracted the best of the usurping nation. But these individuals inevitably discovered that chivalry, nobility, and bravery were no longer viable in the political reality of imperialism. They had become, in Hannah Arendt's words "the tragic and quixotic fools of imperialism."16

One can also call such "fools" romantics. The original virtues of individualism, independence, and inventiveness that had characterized the first intrepid voyagers, and which were still essential in the seventeenth century, became subversive in the nineteenth. Where they had once been indispensable to conquer an overpowering reality because they matched it, such individuals were now considered antithetical to the norm. In literary terms this corresponded to the romantic movement in the last quarter of the eighteenth and the first half of the nineteenth centuries. In imaginative and psychological terms one can trace a connection between the early mariners and travelers, the mercantile lords of the seventeenth century, and the writers and other nonconformists of the nineteenth and twentieth centuries. Romance had become the province of "tragic and quixotic fools," and acquired thereby the sensibilities we associate with modernist literature: doubt, disaffection, and estrangement. The best of colonial literature conveyed that characteristic romantic sensibility.

Two nineteenth century French critics (Duvergier de Hauranne and Ludovic Vitet) found romanticism's most distinctive feature to be independence, stating that it was "a lively coalition of various interests, but with one goal, warfare against the rules, the rules of convention" ("une coalition animée d'intérêts divers, mais qui a un but commun, la guerre aux règles, aux règles de convention"). ${ }^{17}$

In 1829 Victor Hugo asserted in the preface to his play Hernani that romanticism was militant and "nothing other than liberalism in literature." In the 1826 preface to his poetic works, he had explained the distinction between conventionality and romanticism in terms of nature, contrasting a primitive American forest with the manicured royal garden at Versailles. The first, he found to display a "beauty devoid of rules" ("beau sans les règles") that was like "original poetry" ("poésie originale"), while the royal domain had merely "conventional beauty" ("qui est beau de convention") that corresponded to an "artificial literature" ("une litterrature artificielle"). And he proclaimed that there was an order in wild nature; and order, be it in literature or politics, he found to be "marvelously compatible with freedom" ("l'ordre se concilie merveilleusement avec la liberté"). ${ }^{18}$

Hugo went on to draw the important distinction--important in that it counters the standard charge against romanticism: that it loved chaos--between order and regularity. Regularity is only concerned with exterior form, with materiality, and

16. Ibid., p. 209.

17. The quotes about romanticism come from a convenient edition of passages on romanticism in German, French, and English literature: European Romanticism, ed. Lilian R. Furst (London: Methuen, 1980), pp. 43-45.

18. See ibid., pp. $43,100-102$. 
all it can do is systematize; but order is of the very essence of things, is divine, and it creates. "Regularity is the taste of mediocrity, order is the taste of genius" ("la régularité est le goût de la médiocrité, l'ordre est le goût du génie"). ${ }^{19}$ Hugo's distinction applies just as much to my view of the course of Dutch colonialism: that is the transition from an age of heroism to one of prudence, from order to regularity, while it also corresponds to Hannah Arendt's distinction between the "old adventurers" of the colonial trade and Conrad's hollow men of imperialism. It was against the regulatory mediocrity of later Dutch imperialism that the best of Dutch colonial writers rebelled, as did the authors of romanticism. Stendhal, for one, knew that "it takes courage to be a romantic, for one has to take risks" ("Il faut du courage pour être romantique, car il faut hasarder"). ${ }^{20}$ Or, as Hugo put it, there may be dangerous beasts lurking in the jungle while in a French garden you'd find harmless creatures; and yet "we prefer a crocodile to a toad," an opinion that sounds even firmer in the original: "nous aimons mieux un crocodile qu'un crapaud."

One of the greatest contributions of romanticism was a radically different attitude to language and style, to the "false refinement" and "poetic diction" of neoclassicism. In the preface to his lyrical ballads published in 1800 , Wordsworth asked for a language that was "really used by men," by rural people for instance, who lived a simple life close to nature, and who would therefore "convey their feelings and notions in simple and unelaborated expressions." ${ }^{2 I}$ Or, we might add, the English authors of the old travel narratives of the sixteenth and seventeenth centuries, who wrote like their Dutch competitors and provided Wordsworth's friend Coleridge with an abundance of marvels, described in a pithy and sinewy style, for his "Rime of the Ancient Mariner." The desire for a more direct and unadorned style should logically coincide with a revitalization of prose works. And indeed one will find that, despite more derogatory notions of romantic literature--that it is sentimental, effusive, fanciful, or bizarre--that one of the great services of the romantic movement was, paradoxically, its realism, its genius for prose, and its important contributions to the development of the novel. Nor was this new style dull, routine, or tedious. Hugo's dislike of regularity and mediocrity argues against that. In fact, Russell Noyes, a scholar of romanticism, characterized Byron's style in Don Juan as "an amazing medley of wit, pathos, roguery, cynicism, beauty, satire, and ribaldry. . . This later poetic style approaches remarkably near to the prose of his inimitable letters written in Italy." ${ }^{22}$ Noyes went on to say that "the closer Byron comes to prose in his poetry the nearer he comes to humanity and the real world he knew ; and paradoxical though it may sound, the closer he comes to poetry."

In a letter from Samoa written in 1893, Robert Louis Stevenson summed up this fundamental conflict of styles--a choice any writer has to face--as the difference between "naked writing" and writing that has a "coloured veil" over it. ${ }^{23}$ My contention is that a "naked style" is the hallmark of the best of Dutch colonial literature, if not of colonial literature in general. We already saw it to advantage in the modest and untutored style of van Linschoten and Bontekoe and similar writers at

19. Ibid., p. 102 .

20. Stendhal, Selected Journalism from the English Reviews, ed. Geoffrey Strickland (London: Calder, 1959), p. 5.

21. European Romanticism, pp. 11-13.

22. English Romantic Poetry and Prose, ed. Russell Noyes (New York: Oxford University Press, 1956), pp. 786-87.

23. Robert Louis Stevenson, Vailima Letters, ed. Sidney Colvin, 2 vols. (New York: Scribner's, 1906), 2, p. 137. 
the beginning of Dutch colonial literature. Indeed, one could argue that it is only natural that such an unaffected mode of writing should be affiliated with colonialism because it represents the voice of the merchant caste. Daniel Defoe, who wrote a kind of prose that was greatly admired by Joyce, noted in The Complete English Tradesman that "as plainness and a free unconstrained way of expression is the beauty and excellence of speech, so an easy concise way of writing is the best style for a tradesman." 24 And here one finds a link with adventure literature again because Defoe wrote the classic modern adventure novel in Robinson Crusoe, a book that, among other things, celebrated the protestant and capitalistic spirit of imperialism.

My contention also holds true for colonial literature in English. Kipling, who is one of the finest prose stylists in the English language, is a good example. His mode of delivery has been called "sparse" ${ }^{25}$ and is said to have been tooled by his experience as a journalist in India. In the story "William the Conqueror" a man is asked to write dispatches about such a dramatic event as a famine, but with the proviso that he would write "nothing sensational, of course, but just plain facts about who is doing what, and so forth"; later on he is said to tell his tale "in few words, as it might have been an official report." ${ }^{26}$ Similarly, in a recent and long overdue reappraisal of Kipling as a literary artist, the American critic Irving Howe notes that "the political issues raised by Kipling's Indian stories, though still troubling, are slowly fading into the historical background, and the way is now clearer for the vibrancy of Kipling's language, the richness of his imaginings." Howe also feels that Kipling's ability "to write incisively" may be due to his youthful career as a newspaperman. Like Defoe, Kipling grounded his art in fact, and this granted him a "plastic vividness" and "an interest in small doings." Howe sums up Kipling's final achievement as a prose artist in a manner that is similar to this discussion of romantic and colonial styles. Kipling, according to Howe, was a craftsman of English prose who grew ever finer until "he became a master of one of the purest English prose styles--incisive, flexible, a model of what might be called the demotic middle-style." 27

Howe's characterization of this naked style as demotic and Defoe's emphasis on its spoken heritage are combined in Anthony Burgess' interpretation of Somerset Maugham's Malaysian stories. The way these tales are told, according to Burgess, "suggests a man sitting down with his friends after a game of bridge and, over glasses of whisky and soda, spinning a plain tale. Maugham's style of writing is a spoken style--easy, unforced, totally relaxed. It is, if you like, an 'unliterary' style." 28

In Dutch colonial literature, too, we find such "actor[s] with a pen" as Elias Canetti characterized the novelist in Die Blendung. The colonial style, if one may call it that, was based on the rhythms of oral narrative, patterning itself after the

24. Quoted in Green, Dreams of Adventure, p. 11.

25. John A. McClure, Kipling and Conrad: The Colonial Fiction (Cambridge, Mass.: Harvard University Press, 1981), p. 6.

26. Rudyard Kipling, The Day's Work (New York: Doubleday \& McClure, 1899), pp. 201, 218.

27. Irving Howe, "Reconsideration: Rudyard Kipling," The New Republic, 186, no. 6 (February 10, 1982), pp. 32-33.

28. Maugham's Malaysian Stories, ed. Anthony Burgess (Kuala Lumpur: Heinemann [Asia], 1975), p. xiii. 
stories people told each other in the cool of the evening after a long, hot, tropical day. The most famous instance is the work of Eduard Douwes Dekker who, under the pseudonym of Multatuli, wrote perhaps the most famous novel of Dutch literature, Max Havelaar. Quite apart from its vehement denunciation of colonialism, this book was a literary bombshell because of its style. One must have read the bloodless productions of nineteenth-century Dutch prose to realize its extraordinary vitality and vivacity.

The following passage from Chapter 9 of the book shows Multatuli's mockery of tawdry romanticism, although he was not loath to use it himself. He is addressing the average reader of the nineteenth century who is only content with reading fodder, and who has no sympathy or understanding for the writer's labor and plight.

I can imagine that your wife asks: "Is that book any good?" And you say for example--horribile auditu for me--with the large vocabulary so typical of married men:

- - Hm . . well ... I'm not sure yet.

Allright, barbarian, read on! The most important thing is right on your doorstep. And I stare at you with trembling lips and measure the number of pages you've turned, and I search your face for the reflection of the chapter "that is so beautiful. ..." No, I say, he hasn't gotten there yet. In a moment he'll jump up, embrace something with ecstasy, perhaps his wife. . .

But you read on. I would think that you've passed "the beautiful chapter" already. You didn't jump up at all and didn't embrace anything. . . .

And the number of pages under your right thumb is growing smaller and smaller, and my hope for that embrace is growing faint . . . indeed, I was even counting on a tear!

And you have read the novel up to "boy meets girl," and you say--another form of marital eloquence--with a yawn:

-Well . . well! It's a book that . . hm! Ah well, they write so much these days!

But don't you know, monster, tiger, European, reader, don't you know that you've just spent an hour chewing on my spirit as if it were a toothpick? With gnawing and chewing on the flesh and bone of your own kind? Cannibal, my soul was in it, my soul that you ground up once again as if it were your cud! It was my heart that you gulped down as if it were a candy! Because I put my heart and soul in that book, and so many tears fell on that manuscript, and my blood shrank from my veins even when I wrote it, and I gave you all of this, and you bought it for a few nickels . . . and you say: hm!

The reader understands of course that I'm not referring to my book. ${ }^{29}$

As a Dutch critic has pointed out, the reason that the Indies made Dekker such a good writer was that over there he was not hamstrung by the literary canons of decorous style prevalent in nineteenth century Holland. On every page of his considerable oeuvre, Multatuli is said to "speak to those absent as he would have

29. This and all subsequent translations are mine. The tone and diction of the last paragraph remind one of Baudelaire's introductory poem, "Au Lecteur," to his Fleurs du Mal. This is chronologically possible since the famous obscenity trial took place in 1857 after the publication of the first edition of the poems, while the second edition appeared in 1861. Multatuli finished his manuscript in October of 1859 . 
spoken to those who were present; the 'praatbrief' is the elementary form of Multatuli's prose." ${ }^{30}$

Other instances of this conversational style can be found in the more recent work of Friedericy and Alberts. In such novels as De laatste generaal (The Last General) or De raadsman (The Counselor) Friedericy used an apparently simple style that is deceptive because the constraint of adjectival sentiment and the unruffled syntax is carefully crafted. Friedericy told a reporter once that he rewrote The Counselor six times. Despite his reserved manner, Friedericy was known by intimates as a gifted story teller. It was considered a rare privilege to hear him present a tale. The experience was described by his friend, Alberts, as follows. "He really gave a marvellous performance, walking back and forth, gesticulating and, especially, miming to a circle of people who were breathless with suspense. He told short and longer stories, masterfully constructed up to and including the final word." 31

Alberts, himself one of Holland's most outstanding living writers, published another colonial masterpiece, entitled $D e$ eilanden (The Is/ands). His work, too, is characterized by a plain style and understated delivery. His sentences are frequently short, declarative, and in the active voice. The diction is seldom abstruse, it is niggardly in its use of adjectives, and the frequent dialogue is straightforward and repetitive. Yet Alberts manages to convey a profound mystery that is seductive and unforgettable.

If one continued to catalogue names such as Walraven, Dermoût, Beb Vuyck, Nieuwenhuys, the letters of Van der Tuuk, or the descriptions of Java by Junghuhn, one would have a checklist of some of the best prose that Dutch literature has to offer.

Up to this point I have tried to argue that a naked style was the best literary vehicle for colonial fiction. But perhaps one should also ask why this is so. The answer is fairly simple.

I mentioned that in the early travelogues realism still had the lure of romance. In historical terms that ceased to be true in the nineteenth century, though imaginatively it persisted into the twentieth century. From the point of view of Europe, the narrative material would always appear theatrical, expansive, and extravagant, and thus romantic. To put it as simply as possible: the reason why the best of Dutch colonial literature was so much better than what was being produced at the same time in Holland, is that the narrative elements were far more fascinating and dramatic than anything an average Dutchman could possibly experience at home.

Consider, for instance, the following description:

Kisiwa Kilwa, the island which separates the harbors of Sangarungu and Kilwa Kisiwani, is three and a half miles long north and south, low, and covered with trees. The northern part of the island is a coral plateau, fifty feet above the sea; on it are many large baobab trees. The fringing reef,

30. The neologism praatbrief refers to the noun brief [letter] and the verb praten [to speak]. In other words, Multatuli wrote as if he were talking to his audience, or as if he were writing a letter to intimates back home.

31. A. Alberts, "In Memoriam H. J. Friedericy," De Groene Amsterdammer (December 1,1962$)$. 
which dries, follows the line of the east coast. The ruins of old Quiloa, on the northwestern part of the island, are extensive but mere foundations, except the ancient Arab castle. They include an embattled space, the walls of which are still standing. The ancient Arab Castle, standing among the ruins at the northwestern part of Kisiwa Island, is a tall conspicuous keep-like fortress and may be seen from a distance of ten miles in the morning sun, as may also the baobab tree about half a mile eastward of it. Range beacons are located in the southwestern corner of the bay. The front beacon is a white rectangular beacon, with a cone top, erected on the southwestern point. The rear beacon, some 380 yards from the front beacon, is a black wooden diamond mounted on the trunk of a tree.

This is not a description by Conrad or Kipling but part of sailing directions for the southeastern coast of Africa, published by the United States Navy in $1936 .{ }^{32}$ Somerset Maugham, who played a similar trick in his story "The Vessel of Wrath," asked if "the imagination could want more material than this to go on a journey through time and space?" With regard to pilots like the one I have just quoted, he remarked that "these business-like books take you upon enchanted journeys of the spirit; and their matter-of-fact style, the admirable order, the concision with which the material is set before you, the stern sense of the practical that informs every line, cannot dim the poetry that, like the spice-laden breeze that assails your senses with a more than material languour when you approach some of those magic islands of the Eastern seas, blows with so sweet a fragrance through the printed pages." 33

This applies, of course, just as well to the sixteenth and seventeenth century rutters mentioned before. Here three centuries of literature have found a common ground for comparison.

Why indeed embellish with Stevenson's "coloured veil" that which is extraordinary in plain fact? Using Defoe's "tradesman style" in this context can be construed as a shrewd and sophisticated choice which, incidentally, casts an entirely different light on the naive accounts of such writers as van Linschoten or Bontekoe.

Here we also have the reason why a great deal of popular writing about the tropics in the nineteenth century has failed to withstand the test of time. The intemperate rhetoric and emotional extremism of many, once popular, authors was inauthentic and romanticism at its worst. Some of those forgettable authors are French writers like Pierre Loti and Psichari, ${ }^{34}$ or Dutch authors as Johan Fabricius, Annie Foore, Melati of Java, Augusta de Wit, Szekely-Lulofs (who became very popular outside Holland with novels such as Coolie and Rubber) or the American novelist Vicky Baum who wrote a very successful novel called Life and Death in Bali. Their characters were clichés, the plots were hackneyed, and everything was inflated by hyperbole. This was the tropics of travel folders, reading fodder for people who wanted drama that was mawkish and a fictional atmosphere that was always moist and pungent with spices.

One should not, however, forget that these musty products were once very profitable even if they gave colonial literature a bad odor. Their trite imagining

32. Sailing Directions for the Southeast Coast of Africa, 3d ed. (Washington: US Government Printing Office, 1936), pp. 253-54.

33. Maugham's Malaysian Stories, pp. 1-2.

34. See Alec G. Hargreaves, The Colonial Experience in French Fiction (London: Macmillan, 1981), pp. 21-112. See also: Martine Astier Loutfi, Littérature et Colonialisme. L'expansion coloniale vue dans la littérature romanesque française 18711914 (La Haye: Mouton, 1971). 
intuited that there was now a darker side to life in the tropics, a side that usually took the form of describing the destruction of the dissolute European: either by a languid surrender to a death caused by physical or mental ruin, or by a violent and lethal explosion of despair. The historical background for that fiction has already been mentioned. The erstwhile energy of daring individualists who went against the grain in order to forge a rough dream had, by the first quarter of the nineteenth century, become a liability to a governmental system that had institutionalized regularity, prudence, and the status quo. But in fact the colonial reality was now a bureaucratic hierarchy, deeds of daring were bled white by ledgers, and benign conformity had usurped the throne of the despot who, even at his most rapacious, had been open about his designs.

One cannot feed a dream on a steady diet of administrative red tape. Trappings of grandeur had become the illusion of the bourgeois, and were trivialized. Even aristocracy now meant, more often than not, that one had to have the right connections. The concept of aristocracy had to be reformulated. During the nineteenth century it found a new life as a nobility of idealism, with its corresponding disdain for the plebeian hierarchy of clerks, those drones who kept the imperial hive humming. Or it could take the form of a willful isolation defined by a certain style of living, a contempt for conventionality that granted eccentricity a distinction previously reserved for the upper classes. The members of this inverted and subversive aristocracy, titled by dissent, were Hannah Arendt's "tragic and quixotic fools of imperialism." The descendants of the early mariners and marauders had from necessity become intellectual iconoclasts and discontented writers. Reality would never be a romance again. The sadness of this condition made the literary equivalent even more romantic and modern, because, as Madame de Staël already postulated in 1800: "melancholy poetry is poetry that is most in tune with philosophy. Sadness goes deeper into man's character and destiny than any other disposition of his soul" ("la poésie mélancholique est la poésie la plus d'accord avec la philosophie. La tristesse fait pénétrer bien plus avant dans le caractère et la destinée de l'homme, que toute autre disposition de l'âme"). ${ }^{35}$

Eduard Douwes Dekker, who lived from 1820 to 1887 , is a good example of this more modern, this illicit nobility. His Max Havelaar became a cause célèbre and remains the most widely translated text of Dutch literature. And I consider it no accident that Multatuli may well be Holland's greatest romantic author.

The private man Dekker and the public persona Multatuli together form a complicated and puzzling entity. To do him full justice would take considerable time and require an intimate knowledge of his extensive oeuvre. For the moment I will confine myself to a number of salient features of his life and work to illustrate my argument.

Dekker was born in Amsterdam. His parents were respectable members of the middle class, proper people who were devout Protestants with just enough money to raise their children well. He was eighteen years old when he went to the Indies, where he found employment in the colonial civil service. His first major appointment was as "controleur second class" in Sumatra in 1842. I should mention that something of the old colonial order had survived in what were called "the outer possessions," that is to say, any area outside Java. Only twenty-two years old, Dekker enjoyed in Sumatra considerable freedom as the chief civil official. There was no direct official restraint, and he was charged with a remarkable variety of functions: such as, among others, head of police, judge, president of the native court, postmaster, and revenue agent. Even in that early stage of his career, his

35. European Romanticism, p. 20. 
sympathies were entirely with the native population; he readily disagreed with his superiors, and frequently ignored bureaucratic decorum. Only nine months after his arrival he came into open conflict with his autocratic superior, Governor Michiels. Dekker was accused of administrative shortcomings and financial mismanagement.

The fiscal problem is complicated, but there seems no doubt that there was a deficit in his accounts, and that he later was forced to reimburse the colonial government. ${ }^{36}$ Throughout his life Dekker was notoriously cavalier about money, handling it irresponsibly. An indifferent bookkeeper who was ever willing to help people when regulations or reality prescribed prudence, I imagine that he considered accounting for his expenditures a mundane irritation, and would have rather dealt with money in the expansive manner of an aristocrat who is above such vulgarity. At any rate, when he came to Padang he discovered that Michiels was going to punish him in a manner disproportionate to the alleged crime. Soon after he arrived, Michiels forbade him to leave the area, withheld his salary, and, during the first days of 1844 , stripped him of his position and remuneration.

For almost a year Dekker was forced to live penniless, dishonored, ostracized by the Dutch community under suspicion of fraud, but forbidden to leave. Soon the only things he had left to sell were his clothes, and he sold them item by item. He often went without food and once was saved from starvation by a Chinese. But Dekker refused to knuckle under. He stole potatoes from the fields, stole a turkey (which he returned to its owner when he found out it did not belong to Michiels), and wrote epigrams about his tormentor. Far from yielding under pressure, Dekker flaunted his desperate position and was called a "lunatic" and "the eccentric lord," labels that must have pleased him. ${ }^{37}$

But those clashes with authority should not hide the fact that what Dekker succumbed to in Sumatra and, later, in Celebes and Ambon (all outer possessions) was, what one might call, the exuberance of power. When he was in his fifties Dekker wrote the following passage about the effect of such uncustomary prerogatives.

I was not even twenty-three years old when I was "kommandeur" of the province of Natal. The duties of such an official are most pleasant, and in later years I have often wished myself back to that position which at the time, due to inexperience, I did not value enough. . . . A person is even a little more than being first in such a place. He is everything [sic], and many a Caesar would be satisfied with that. It is true that the exalted position such an official enjoys is in reality due to the emptiness around him since he is often, except for the military commander, the only European there, if not of the entire province. But if one comes to the Indies while still young, hence with enough time to get used to the place, then one will soon feel perfectly at ease when coming in contact with the natives. The emptiness of the white man's hermitage is supplemented by a kind of royal dignity regarding the population which, in turn, takes the exaltation of the official quite seriously. In fact, more seriously than he does. The most venerable native chiefs treat him with childlike respect, and he is called "father" by gray-beards. But one should not think--a European delusion--that such relationships are regulated according to Law. The native neither knows nor understands our subtleties of authority. When one is the lord one is in charge of everything and has almost unlimited power. . . A native chief

36. See Multatuli, Volledige Werken, ed. Garmt Stuiveling, 14 vols. (Amsterdam: Van Oorschot, 1973-1982), 8, pp. 289-95; and Du Perron, Verzameld Werk, 4, pp. 84-91.

37. See Multatuli, Volledige Werken, 8, p. 297; and Du Perron, Verzameld Werk, 4, pp. 80-96. 
will just as humbly ask for the approval of [his] lord for the intended marriage of his daughter as for the planning of new pepper plantations. Such a cordial and patriarchal relationship is far more pronounced in Sumatra and some other outer possessions, than in Java. The Javanese is more submissive, but in the daily association with people he won't furnish such pleasant instances as, for example, a Malay whose affection is more valuable because he has more character. It stands to reason that if one is invested with authority in the unspoiled interior of Sumatra one can do a great deal of good. I regret even now that I did not make greater use of it. But I was too young, much too young. ${ }^{38}$

When he was back in Java after the Sumatra affair, Dekker was admitted again to the ranks of the colonial bureaucracy. In 1846 he married Everdine Huberta van Wijnbergen, an orphaned and impoverished baroness. After postings in Java, Celebes, and Ambon, he went back to Holland in 1852 for a two-year furlough.

It appears that within less than a year he was without adequate funds. Dekker armed himself with a foolproof system and set out to acquire a fortune in the casinos of Belgium and Germany. Predictably he lost, as he would continue to do in future years. The notion that his wife was owed a substantial sum from her family proved to be false, and Dekker had no other recourse than to ask the authorities for advances. He seems to have seriously considered not returning to the Indies, convinced that he would be a rich man soon, but everything failed and after several extensions of his leave he returned to Java with his wife and newborn son in 1855 .

Back in the Indies he was confronted with yet more financial problems--deficits from his tenure in Celebes and Ambon. In January 1856 Governor-General Duymaer van Twist appointed him assistant-resident in Lebak, in the residency of Bantam in western Java. He assumed his post on January 22, 1856, and left on April 20, barely three months later, after being granted an honorable discharge from the colonial government. He was in Java for roughly one more year and left the Indies in April 1857, alone, leaving his pregnant wife and young son behind. He never saw the tropics again.

The Lebak affair, which was the cause of his discharge from the civil service and the central issue in Max Havelaar, is complicated and controversial. Suffice it to say that Dekker accused the native regent of extortion and of making unlawful use of his Javanese subjects as unpaid laborers. Dekker claimed all of his life that he wanted nothing more than to improve the sorry plight of the Javanese peasants. The crucial point, it seems to me, and contiguous with his romanticism, is that he abstracted the regent's minor infraction of using too many grass cutters into the apodictic truth that the Javanese were exploited and mistreated. It is this leap from the particular to the general that reminds one of the revolutionary philanthropy of the English romantic movement. To put it as simply as possible: there is no arguing with a general truth. The difference between the particular reality of Javanese and colonial society in the middle of the nineteenth century, and the incontestable truth that the common man on the island of Java did not live according to Rousseau's social contract is the difference between theology and faith. The first can be argued, the latter only embraced.

It was reality that defeated Dekker in Java. In an article about the official relationship between the colonial government and the native regents, C. Fasseur asserts that an official policy existed whereby the dismissal of a regent could be recommended if enough proof of sufficient importance had been furnished. "But," he notes, "Douwes Dekker lacked the tact and circumspection to achieve his goal,

38. Multatuli, Volledige Werken, 6, pp. 415-16. 
which was the removal and dismissal of the Regent." ${ }^{39}$ And reality defeated him once again in 1860 when the publication of Max Havelaar did not result in some kind of revolution, when Holland's king did not publicly confess to the sins Dekker accused him of, when the Governor-General of the Dutch East Indies did not commit political suicide, and when he was not given an exalted position in the colonial hierarchy as compensation for his sufferings.

His book was a succès d'estime and a succès scandale, but it earned him very little money. For the rest of his life he had to write for a living, and hated every minute of it. Multatuli discovered that it is far easier to be a nobleman of the blood than an aristocrat of the mind. The former can always be respectably poor, but as for the latter, not even the poor pay him any respect.

Dekker also exhibited more tangible characteristics of aristocracy. He defended dueling, for instance, certainly a mode of settling arguments with chivalric overtones. At the age of twenty-two he is said to have fought with sabers in Sumatra without, as he put it with ironic bravado, "ever letting his cigar go out," while in 1881 , at the age of sixty-one, he still thought that "the principle of duelling is useful in a society that does not have a sense of honor." 40 He married a woman of nobility, as if acquiring by proxy the status he would have liked as birthright. He made it clear to his fiancée that he was well aware of their difference in social status, but told her with unfeigned self-assurance that this did not faze him. He wished, in fact, that she were a countess rather than a baroness because he "love[d] aristocracy," and had "a kind of respect for it." The reasons he gave are similar to the ones suggested above. "Understand me correctly, I could raise myself up to genuine aristocracy, but never to a mercantile nobility (which, if you think about it, is nonsense)." And though he admits to still being ashamed of his middle-class background, he can also give her proof of the validity of his aspirations by noting that he had "so often lorded it over all kinds of aristocracy" in the Indies. ${ }^{41}$ But true to Green's contention that the colonial gentry could not deny their mercantile caste, Dekker defended the superiority of his own family background by appealing to virtues that are not necessarily bequeathed by bloodline. He wrote in 1875 that his family "was just below average" social status, and yet he says he never encountered anywhere in the world "a more dignified tone, not even with aristocrats, high nobility and princes, yes, not even among orthodox professors of theology or third-generation parvenus."

Given Dekker's personality, so much akin to the romantic hero, abetted by the colonial experience, it is not surprising that the instigation of colonial aristocracy would cause him to dream imperial dreams. Sietske Abrahamsz, one of Dekker's several young lovers after he returned with his family to Holland, states in her memoirs that Dekker once told her "in a kind of ecstacy" that "he wanted to be Emperor" and that she would inherit the throne as "crown princess of Insulinde." 42 Insulinde was the lovely name Dekker had given to the Indies. "On the coins of the new Empire the artist would depict my head. For the moment my title was to be: Duchess of Sumatra." Admirers of Dekker have taken this to be a playful reverie, but I see it as consistent with the character of the romantic outsider and

39. C. Fasseur, "Het Indië van Multatuli," Over Multatuli [Amsterdam], 3 (1979), pp. 13-14.

40. Multatuli, Volledige Werken, 9, pp. 148, 172.

41. Ibid., 8, pp. 532-33.

42. Ibid., 10, p. 378; also Garmt Stuiveling, "Uit het Multatuli-Museum," Over Multatuli, 4 (1979), pp. 56-57. 
colonial aristocrat who would quite readily use force to oust the tepid prudence of the clerks in a brilliant move of audacious action and make the dominion safe for revolutionary philanthropy. For there is also a romanticism of causes, especially when reality denies validity to a dynamic course of action.

Perhaps at the beginning of the colonial era Dekker's dreams might have been possible, though on a more modest scale to be sure, but toward the latter part of the nineteenth century he had to surrender to the hostile power of reality. Dekker's case is poignant proof that the age of heroism had been replaced by the stultifying prudence of the colonial service. And yet, in him stirred the restless ghost of one of Hannah Arendt's "old adventurers." Denied access to reality, it was forced to take the one route still open: the subversive mode of writing like a genius. And though he hated to admit it, cursed his own talent, was silent for the final decade of his life, Dekker was a writer of genius, with a capacious imagination. When reality would not allow him to conquer the Indies by force, he annexed it in his imagination under the lovely name of Insulinde and bestowed upon himself the sonorous name of Multatuli with its echo of Roman emperors. This was a different kind of wealth.

Because Dekker was temperamentally and artistically a most unlikely Dutchman, and because his manner of living was offensive to the prevailing social norm, it is not surprising that during his lifetime, and for years thereafter, he had to contend with a host of malignant enemies. Most of them were piddling, though vicious, and in the thirties of the present century, another great colonial writer; Edgar Du Perron, took upon himself the task to combat these "lice," as he called them, as if he were stamping out a virulent disease.

Du Perron felt a strong intellectual and emotional kinship with Multatuli. Multatuli was for him a symbol of embattled individualism that was denied its due by the tyranny of mediocrity; Multatuli represented for him what should have been the best of colonialism. But just as important for Du Perron was his perception of Multatuli as an intellectual adventurer because, he felt, his predecessor was at the same time an authentic personality and a great writer because his work was never compromised by a bogus individualism. Multatuli had insisted that for a writer his style is the man, and the reason that a real "style [is] so rare [was] because there are so few real people," since "writing is an imprint of the soul." 43 Du Perron took that as his credo and never shrank from its implications.

$\mathrm{Du}$ Perron expressed in his life and in his work all the themes I have suggested, but they are now brittle from a new mode of loneliness and always under siege. Again I have ignored a great deal in order to emphasize what is relevant for my final illustration.

First of all, Du Perron was a real Indies man, something that Multatuli, despite some fourteen years in the tropics, never was. Du Perron was born in November 1899 in Meester-Cornelis (now Jatinegara), a suburb of Djakarta. His parents were what we might call "old money," and lived on a baronial estate called Gedong Menu. They were landowners who had lived in Java for many generations, and constituted a genuine colonial aristocracy. But by the time Du Perron was born, their world was already in peril. It was precisely their uncompromising individualism and vulnerable dignity which made them susceptible to the onslaught of modern investment policies, to industrial development, and to the ruthless egalitarianism of diligent technocrats. They felt contempt for the civil service and had no truck with modern government.

43. Multatuli, Volledige Werken, 9, p. 115; 2, pp. 86-87. 
As landed patricians they scorned planters and other managerial personnel as parvenus and newcomers who did not mind working for a wage. But they were doomed. They were like spectacular dinosaurs who vaguely sensed that they were losing an invisible battle for survival to small, ferociously efficient rodents who were soon to take over their world. And yet, they would never stoop to fight them on their own level. Like Faulkner's fictional Compton and Sartoris families, they refused to acknowledge the virulence of the colonial Snopeses, who were about to snatch the future away from them. They ignored prudence, efficiency, and economic disasters, and continued living in increasingly isolated splendor, until the money ran out.

Du Perron enjoyed an imperious childhood in that world. Like Kipling in India, he came to know the native world of the Javanese first, though from a superior perspective, to be sure. The person he knew most intimately was his babu Alima, a woman who was almost as close to him for the first fourteen years of his life as his own shadow. In the following paragraph from chapter 19 of his Het land van herkomst, he describes the death of the hero Ducroo's (= Du Perron's) babu:

Shortly after I became fourteen, old Alima died. She had given me some money for my birthday to buy books. I showed her the books I had bought but she paid no attention. She pushed them away and looked at me. There was something grey in the pupils of her eyes and her eyelids were surrounded by a thousand wrinkles. "Ma Lima sudah tua," she said, like the song. ${ }^{44}$ I had paid little attention to her lately. A few days later my mother said that I had to take her to a woman dentist, because she kept on complaining that her mouth was hurting. Alima was shivering. I helped her into a carriage and we arrived at a rough creature with a face twice as wide as anybody else's who took one look at Alima's poor teeth and decided to pull all of them. She threw the thin little woman in a chair and I couldn't do a thing about it. She pushed her head back, opened her mouth and went at it as if she were cracking nuts. Alima only moaned softly. When she came home she felt worse than before. The brutal treatment was completely unnecessary because what she thought was a toothache was in reality a symptom of something else. Two days later she was dead. It was the first corpse I had seen. Her face had changed beyond recognition: the mouth was black and distorted into a rigid smile, her face wasn't brown anymore but yellow. She had died while unconscious, without saying farewell to anybody. I went along when they carried her to the native cemetery. The Sundanese deny the fearful aspect of death by acting as normal as possible. The pallbearers were joking among themselves and I got angry and asked them to be quiet. We walked quickly, and at the end somberly, to the grave. I don't remember anything else; putting somebody away in the ground was never the decisive moment of leave-taking for me.

Du Perron was seldom mistaken for a Dutchman. He had, for instance, what was considered a typically Indies face with its kulit langsep complexion, so called after a fruit of a light yellow color with a skin like that of a peach. He did not leave the Indies until he was twenty-one, and towards the end of his life he spent another three years in Java. Of his short life of forty years, more than half was spent in the Indies.

With considerable capital from the sale of their Javanese landholdings, Du Perron's parents left for Europe in 1921 and lived there for the remainder of their lives

44. The Malay phrase "Ma Lima sudah tua" ["Ma Lima is old already"] was a line from a song she used to sing to him as a baby. 
very much like innocents abroad. Their son joined them a few months later. His father bought another baronial estate in Belgium, near Brussels. It has been suggested that a dubious countess succeeded in selling him the place for an exorbitant price because she knew how to flatter his aristocratic inclinations. ${ }^{45}$ The father quickly exhausted his wealth and, a broken and disillusioned man, committed suicide only five years after his departure from Java. His wife died six years later. Du Perron was shocked to discover that there was nothing left of the family fortune. Used to treat money in a cavalier fashion, he suddenly found himself penniless and, like Multatuli, he too had to rely on his writing for his livelihood.

During his four years in and around Paris, Du Perron knew or became friends with a considerable number of younger French writers and artists. He became particularly intimate with Pascal Pia and André Malraux. Malraux dedicated La Condition humaine (1933) to Du Perron and, when he published his memoirs thirty years later, still remembered him as his best friend. Du Perron also became closely associated with just about all the important Dutch writers of the interwar period. There is no doubt that Du Perron was among the foremost minds of his generation. But it is his Indies heritage that makes Du Perron representative of the inversion I see in colonial literature: that displacement of physical and material virtues to an intellectual and imaginative level that is also characteristic of modern romanticism.

Du Perron was a consonant man: there was no discord between his beliefs and his actions. Honest and vulnerable to both his enemies and his friends, he felt deeply hurt when he thought that someone had betrayed him, particularly if it was someone who refused to match his exalted opinion of friendship. Du Perron was also an intensely loyal man, always faithful to an intellectual position, a personal code of honor, or, quixotically, to the vows of marriage. But he was at the same time almost constitutionally averse to anything that so much as hinted at a group mentality, and always scorned opportunities to hunt with the pack.

None of these virtues are an asset for a company man, but they do fit the description of Martin Green's "aristomilitary caste," or Hannah Arendt's "old adventurers." And the notion of adventure was very important to Du Perron. This is adventure in the romantic sense of a trial of one's luck, to seek out risks in a novel and exciting fashion, to commit oneself to an impetuous action that flouts prudence. Although adventure came to mean for Du Perron an intellectual raid on the formidable bulwark of collective compromise, at first it derived directly from his reading as a boy in the Indies.

It is one of Du Perron's most endearing traits that he never became disloyal to the greatest heroes from his youth. Without a trace of false modesty or intellectual embarrassment he stated later in life that Alexandre Dumas' The Three Musketeers "outshone everything; d'Artagnan's rapier cleared away everything that had come before. In the final analysis, d'Artagnan, Athos, Porthos, and Aramis were to me what the heroes of the lliad must have been for the Greeks: at the same time example and poetry, in a word, myth." At a later date he added that the fictional musketeers surpassed their historical models because they were "adventurers, soldier of fortune types, and bohèmes; in the most famous volume they represent the resourcefulness of poverty, friendship, and good humor." ${ }^{46}$ This evergreen of adventure tales embodied for Du Perron the myth of men who could be heroes without losing their humanity, of friendship that was sacred, of loyalty that was never troubled by doubt, and of a kindness that was buttressed by decisive action. Note

45. Pascal Pia, Parler de Du Perron (Utrecht: Editions Reflex, 1979), p. 14.

46. Du Perron, Verzameld Werk, 5, pp. 259, 257; also 2, pp. 129-30 and 604 . 
the emphasis on such terms as "adventurers," "soldiers of fortune" and "bohèmes." For Du Perron, these terms were almost synonymous, describing for him those people who had seceded from conventionality, people who led irregular lives and who were unfit for normal society. That would also describe those early mariners very well.

Furthermore, there was a veritable d'Artagnan cult in the Indies of Du Perron's youth. A serialized movie version of Dumas' masterpiece ran for many months in most local cinemas, and the popular theater group "Komedie Stamboel" had a dramatic version in its regular repertoire. Fencing became the favorite sport and for quite some time a schoolboy thought of no other hero. ${ }^{47}$

The three musketeers represented a myth for Du Perron that he never quite relinquished. And he was both right and honest when he observed that more intellectually approved authors such as Balzac, Stendhal, Conrad, or Malraux were, in a certain sense, nothing more than a psychologically and aesthetically subtle refinement of the writers of adventure tales. ${ }^{48}$ Stendhal (1783-1843) for instance--who, along with Multatuli, was Du Perron's favorite author--was a master of romantic realism, of dramatic adventure and tragic irony. And Stendhal thought of himself as a melancholy rebel in an unrebellious age who wrote "for the happy few" who would recognize his genius after his death.

Stendhal wrote some of the finest criticism of modern French literature in a "cool and easy style," as Henry James described it, that was intelligent, courageous, and irreverent. The same thing can be said of Multatuli's work or Du Perron's own writing. Such a style was also the basis of Dumas' narrative genius. It was energetic, vivacious, and direct, and avoided attracting attention to itself in order to allow events and characters their primacy. It is the vehicle of telling stories successfully, especially if their material is uncommonly dramatic or violent.

What formerly could still be a certain kind of physical behavior had to be transferred to the life of the mind. D'Artagnan's rapier was turned into a sharp pen. Du Perron became a feared and indomitable polemicist. So was Multatuli or Stendhal. So was Byron, for that matter, who was greatly admired by Multatuli, by Stendhal, and by Du Perron himself. ${ }^{49}$ The French phrase for such a writer, un écrivain de combat, retains some of the flavor of danger and excitement usually associated with military life. But Du Perron was not in the literary trenches for love or sport. He fought for a cause. That cause was, specifically, to flay the provincial skin of Dutch letters and society and force it to become a member of a European intellectual commonwealth. On a larger scale, Du Perron fought against the pervasive mediocrity of his day and age.

During the thirties he noticed that this mediocrity was becoming malevolent and militant. The mob was taking over under the banner of fascism, and Du Perron realized that this was a far greater evil than intellectual Babbitry. And quite consistent with his character, Du Perron acted in a manner that was quixotic because it was honorable, in other words, it was romantic. In 1933 he had published a sharp attack on a Dutch critic called Dirk Coster. Five years later he destroyed the remaining copies of the book, not because he wanted to disassociate himself

47. See Nieuwenhuys, Oost-Indische Spiegel, pp. 387-88; Nieuwenhuys' section on Du Perron is in ibid., pp. 377-401.

48. Du Perron, Verzameld Werk, 5, p. 260.

49. J. H. W. Veenstra, Multatuli als lotgenoot van Du Perron (Utrecht: Reflex, 1979), p. 13. 
from his earlier opinions but because, as he stated in a public notice in a Dutch newspaper, his quarrel with Dirk Coster was only a literary one. He had felt that "in the battle which is now fought against barbarism, I see $\mathrm{Mr}$. Coster as such a decent person that my attack seems overdone. Long live Mr. Coster, particularly if one thinks of the future Dutch Goebbels." ${ }^{50}$ That was indeed a rare and chivalrous gesture.

Edgar Du Perron represents the best of the colonial tradition, but he paid a price for it. Like Multatuli, he considered himself superior to the mob, and did not mind confessing that he was an elitist. ${ }^{51}$ He realized that this was a form of militant romanticism that vowed never to give in to apathy, and never to shirk a sense of responsibility. "Don't we," he wrote to a friend, "don't we romanticize our relationship to dictatorship, to the freedom of speech, to our friends? It is so much easier to leave things be. So why is it that we don't?" ${ }^{52}$ The answer is that for this intellectual d'Artagnan, taking a stand was second nature.

And yet, despite these undemocratic virtues, and despite his identification with what was the best of the past, Du Perron was an unhappy man. The legendary world of his parents was gone almost from the moment he was born. The Indies he grew up in was drastically different from the one he had thought to inherit. And when he went to Europe he found himself a stranger in a strange land: despite his French surname he was Dutch, despite his Dutch citizenship he was an Indies man, and though an Indies man he refused to identify with imperialism. No matter where he lived he felt like a displaced person who was uprooted and nowhere at home:

Someone who went back [to the Indies] not that long ago wrote: "Don't come back. The Indies aren't what they used to be. You won't like it, "and so on. My memories, nothing else; memories from a time when I experienced that particular beauty without paying attention to it, without ever trying to restrict myself to it, always distracted because Europe was on the horizon and I thought that that was my real fatherland. And now: draw from myself what the Indies must have given me after all and be loyal to the moment when it emerges? Or should I lie and turn my memories into something like a novel, the public's favorite form of reading?

I can tell about it so beautifully; I can make that country come alive for my European friends--especially if they know Dutch. There are people who suggest that I write about it the way I tell about it. That isn't done that easily. My Indies accent can't be reproduced on paper, and there are ways that are in bad taste, even if they are effective. And I must also be careful not to lapse into that soppy European exoticism, that false romanticism of a few strangely resonant names, some brown skins, velvet eyes, of that docile oriental soul that for some people never fails to have the desired effect.

In Grouhy [ = a town in France] I longed for the Indies as I did nowhere else. The moonlit nights in Grouhy, the light between the blue firs (so unlike the Indies) on the grass. The rather silly brown star that my mother designed for the middle of the lawn, a somber spot when its shrubs were not in bloom. The gate, and behind it sometimes the barking of dogs (almost like

50. The short notice is reprinted in: E. du Perron, Schrijvers Prentenboek, deel 13 (Amsterdam: Bezige Bij, 1969), p. 43.

51. See J. H. W. Veenstra, D'Artagnan tegen Jan Fuselier (Amsterdam: Van Oorschot, 1962), p. 23.

52. Ibid., p. 204. 
the Indies), but their barking wasn't stubborn or irritating enough--in the end all of this is nothing more than a stirring of my memory. When we went into the night, through the tall iron gate, down the stony village path to the cemetery, the Indies were slowly replaced by romantic Europe: the three oaks standing near the cemetery, two of which were later disfigured when they were struck by lightning, the long, high wall around Grégoire's neglected farm which we called the ghost farm or Wuthering Heights, further on the hedge with holes in it that we looked through to see what there was to see, sometimes shades of horses in the meadow, clumsy European horses, the shining circle of the moon hiding behind the hedge. . . . ${ }^{53}$

Du Perron's sense of selfhood had to be intense in order to sustain him, his intellectual aristocracy was an essential defense against the permanent reality of exile, and a camouflage for the fact that he was often insecure in the ordinary world of daily existence. This is the tragic nature of both modern romanticism, and of the best of Dutch colonial literature: it manifests itself as a desperate stamina that keeps on confronting the fact that a dream has been brutalized and has been superseded by a reality that cannot equal its promise. It is a case of what the late John Cheever in his last novel called "unrequited melancholy." 54

When Du Perron returned to Java in 1936 after an absence of fifteen years, it turned out to be a sad reunion. His health no longer tolerated the physical climate of the tropics. Because he did not have the proper qualifications, he could not find regular employment, and as a writer he was outside the main stream of colonial society. The young man who had left the Indies as something of a prince, was now forced to scrape together whatever money a superfluous scrivener could find.

These three trying years taxed his physical and mental reserves. During this time he annexed Multatuli as a comrade in arms, defending him almost obsessively against the critical nitpickers he called "lice." The maligned genius Multatuli became a mirror for Du Perron to confront his own psyche, because in striking a blow for Multatuli he was exonerating himself.

Typically, Du Perron turned this spiritual alliance into concrete fact. While still living in Java he crossed literary swords with a journalist by the name of Zentgraaff. ${ }^{55}$ A muckraker, who was a crypto fascist and colonial jingoist, Zentgraaff tyrannized colonial society with impunity. Du Perron felt that he had to challenge this inferior reincarnation of cardinal Richelieu as a buaya, a Malay word which means both "crocodile" and "scoundrel." Du Perron won the duel, but it is a sad commentary on the rightness of his views that, only after it became clear that he would emerge victorious, did less courageous individuals find the backbone to join him in the kill.

A graphic illustration of colonial decline is Du Perron's visit in 1938 to his ancestral estate, Gedong Menu, named after his maternal great-grandfather, a colonel Menu. His grandmother had lived there, his mother had inherited it, and he was born there in 1899. Now he had to live with his wife and small son in the outbuildings. In the main house lived a Dutch tailor with his family, who sewed uniforms for the Dutch colonial army. Du Perron stayed no longer than a month. ${ }^{56}$ He had come to the Indies because he was disgusted by the "putrid political atmosphere" in

53. From Het land van herkomst, ch. 2.

54. John Cheever, Oh What a Paradise It Seems (New York: Knopf, 1982), p. 95.

55. This affair is discussed at length in Veenstra, D'Artagnan.

56. See ibid., pp. 100-101. 
Europe, and had hoped to find his tropics again. "I knew that my vision was 'poetic' and that it would be disproved by reality from every side; but I wanted to experience that reality myself so that I would not forever keep on longing for that fairytale reality." 57 To be on what Du Perron would have considered the right side in the Indies of the thirties, he would have had to be an Indonesian revolutionary. He was not that, as he had not been a Parisian or a Dutchman. He now felt that he was deserting his European friends in their desperate struggle against fascism, and in 1939 decided to return to the continent. In Holland on the fourteenth of May 1940, the day the Dutch armed forces capitulated to the German aggressors, Du Perron died of a heart attack.

An age of relative innocence had gone forever. The present evil was one that that earlier age could never have imagined. The literature of modern romanticism and of the best of colonial literature belongs essentially to that troubled era. And yet we feel nostalgic today when we read it. The reason, as Hannah Arendt knew, is a certain guilelessness, despite very real transgressions. She places the demise of the old order between 1884 and 1914, though for the colonial Indies this should be extended to the twenties. Taking that into account, she was very right about the following assessment:

We can hardly avoid [she wrote in The Origins of Totalitarianism] looking at this close and yet distant past with the too-wise eyes of those who know the end of the story in advance, who know it led to an almost complete break in the continuous flow of Western history as we had known it for more than two thousand years. But we must also admit a certain nostalgia for what can still be called a "golden age of security," for an age, that is, when even horrors were still marked by a certain moderation and controlled by respectability, and therefore could be related to the general appearance of sanity. In other words, no matter how close to us this past is, we are perfectly aware that our experience of concentration camps and death factories is as remote from its general atmosphere as it is from any other period in Western history. ${ }^{58}$

Tempo dulu it was once called--time past. But now, after two world wars and several Asian wars, this phrase presents more than a wistful longing for the prerogatives of imperialism; it gives as well a poignant realization that an epoch is past that will never return. At its worst the documentation of this perception is sentimental indulgence, but at its best it is the poetry of a vanished era, of the fall of an empire, of the passing of an age when, in European eyes, issues moral and political were firmer and clearer.

57. Ibid., p. 206.

58. Arendt, Origins of Totalitarianism, p. 123. 
Note:

It will be of interest to our readers to know that a number of the books mentioned in this article have been translated into English and are being published by the University of Massachusetts Press* in a series entitled The Library of the Indies which Professor E. M. Beekman is editing.

The volumes which have thus far appeared in this series are:

The Poison Tree: Selected Writings of Rumphius on the Natural History of the Indies. Edited and translated by E. M. Beekman. $256 \mathrm{pp}$. 1981. Cloth \$20.

Multatuli, Max Havelaar: or The Coffee Auctions of the Dutch Trading Company. Translated by Roy Edwards. Introduction by D. H. Lawrence. Afterword by E. M. Beekman. $352 \mathrm{pp}$. 1982. Cloth $\$ 17.50$, paper $\$ 9.95$.

E. Breton de Nijs, Faded Portraits. Translated by Donald and Elsje Sturtevant. Introduction and Notes by E. M. Beekman. $192 \mathrm{pp}$. 1982. Cloth $\$ 15$.

Rob Nieuwenhuys, Mirror of the Indies: A History of Dutch Colonial Literature. Translated by Frans van Rosevelt. Edited by E. M. Beekman. 442 pp. 1982. Cloth \$27.50.

Scheduled for publication in 1983 is:

E. Du Perron, Country of Origin. Translated by Francis Bulhof and Elizabeth

Daverman. Introduction by Francis Bulhof. $480 \mathrm{pp}$. 1983 . \$25 tentative price.

Forthcoming titles in the series include H. J. Friedericy's The Counselor (De raadsman), A. Alberts' The Islands (De eilanden), and L. Couperus' The Hidden Force (De stille kracht).

* Box 429, Amherst, Mass. 01004. 